\title{
Correction to: The antibacterial activity and toxin production control of bee venom in mouse MRSA pneumonia model
}

Dong-Yeul Kwon ${ }^{1}$, Ryong Kong ${ }^{1}$, Young-Seob Lee ${ }^{2}$, Dam-Hee Kang ${ }^{1}$, Shu Wang ${ }^{1}$, Qianqian Li ${ }^{1}$ and Ok-Hwa Kang ${ }^{{ }^{*}}$

\section{Correction to: BMC Complement Med Ther (2020) 20:238 \\ https://doi.org/10.1186/s12906-020-02991-8}

Following publication of the original article [1], the authors identified an error in order of names of authors. The correct order of authors should be as given below.

Dong-Yeul Kwon ${ }^{1}$, Ryong Kong ${ }^{1}$, Young Seob Lee ${ }^{2}$, Dam-Hee Kang ${ }^{1}$, Shu Wang ${ }^{1}$, Qianqian $\mathrm{Li}^{1}$, and OkHwa Kang ${ }^{1 *}$

\section{Author details}

'Department of Oriental Pharmacy, College of Pharmacy and

Wonkwang-Oriental Medicines Research Institute, Wonkwang University,

Iksan, Jeonbuk 54538, Republic of Korea. ${ }^{2}$ Department of Herbal Crop

Research, National Institute of Horticultural \& Herbal Science, RDA, 92

Bisanro, Eumsung, Chungbuk 27709, Republic of Korea.

Published online: 14 October 2020

\section{Reference}

1. Kong R, et al. The antibacterial activity and toxin production control of bee venom in mouse MRSA pneumonia model. BMC Complement Med Ther. 2020;20:238. https://doi.org/10.1186/s12906-020-02991-8.

The original article can be found online at https://doi.org/10.1186/s12906020-02991-8.

* Correspondence: kangokhwa@daum.net

'Department of Oriental Pharmacy, College of Pharmacy and

Wonkwang-Oriental Medicines Research Institute, Wonkwang University, Iksan, Jeonbuk 54538, Republic of Korea

Full list of author information is available at the end of the article

(C) The Author(s). 2020 Open Access This article is licensed under a Creative Commons Attribution 4.0 International License, which permits use, sharing, adaptation, distribution and reproduction in any medium or format, as long as you give appropriate credit to the original author(s) and the source, provide a link to the Creative Commons licence, and indicate if changes were made. The images or other third party material in this article are included in the article's Creative Commons licence, unless indicated otherwise in a credit line to the material. If material is not included in the article's Creative Commons licence and your intended use is not permitted by statutory regulation or exceeds the permitted use, you will need to obtain permission directly from the copyright holder. To view a copy of this licence, visit http://creativecommons.org/licenses/by/4.0/. The Creative Commons Public Domain Dedication waiver (http://creativecommons.org/publicdomain/zero/1.0/) applies to the data made available in this article, unless otherwise stated in a credit line to the data. 